\title{
Bringing the Hill Home: Teaching Undergraduates about Congress
}

\author{
Thomas Ringenberg, Rockhurst University
}

"If editorial writers and professors of political science actively participated in politics at the precinct level, the experience would open up for them new vistas of intense realism."

-William L. Clay, Sr. (1992), former Member of Congress from Missouri

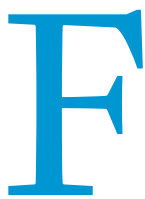

or an early career political scientist of any subfield, there are few opportunities as enriching as the APSA Congressional Fellowship Program. As a newly minted $\mathrm{PhD}$, well versed in the academic research on Congress, I arrived in Washington with an air of confidence that was short-lived. Functioning inside the modern Congress requires skills that are not formed in the graduate seminars of the ivory tower, but in the time-sensitive world of practical politics. Scholars of Congress have much to teach the Capitol Hill community about their institution, but there is obviously much to learn.

The insights gained by APSA fellows during their time in the halls of the Capitol have led to significant progress in our understanding of parties, representation, and legislative behavior. It is no coincidence that some of our best ideas about Congress have come from people who spent time interacting with and observing the institution from within. This transmission of knowledge among the community of political scientists is important. But, I submit the reason scholarly debate grounded in realism and practicality is so crucial is that those debates filter to undergraduates who number in the millions, where the legislative studies section of APSA has a only few hundred members.

There is a growing recognition that our discipline should be taking issues of political science pedagogy more seriously. Though this essay is not the systematic inquiry that makes up the serious scholarship of teaching and learning, I am interested here in discussing the tangible, practical lessons I learned during my fellowship that are transferable to undergraduates in courses on American politics. For those scholar-educators who teach upper level seminars on Congress, interest groups, or public policy_-"all of the above" for many faculty-these lessons will not only help your students reach a better understanding of American government and society, but also be more prepared for careers in the policy-making arenas that support our democracy.

\section{MEANINGFUL ASSIGNMENTS: PROFESSIONAL}

\section{COMMUNICATIONS FOR A PROFESSIONAL WORLD}

One of the most crucial periods of the fellowship year is the placement process. For me, that meant writing about 40 cover letters and sending unsolicited e-mails to various members' offices and committee staff. Obviously, the CV had to be gutted to become a proper résumé. Outside of academia, there is little patience for more than one page of anything. This was my first lesson, and perhaps the most transferable to the undergraduate classroom-professional and concise writing is an essential skill.

I interviewed for a number of possible office placements, in both personal offices and committees. I prepared diligently, reading previous press releases from the offices, investigating staff history and connections, and searching C-SPAN for video clips. This preparation, combined with a new suit, had me feeling confident that I would be in a position to choose among many placements. The free labor of a $\mathrm{PhD}$ for months seemed like an easy sell. But at the end of one phone interview I was hit with a question I was unprepared for: "Thanks, we will be in touch. In the meantime, can you send us a short writing sample?" Having just completed nine straight years of higher education, this should not have been a strange request. But I panicked. I ended up cropping out a few pages from my dissertation, hoping my data analysis skills would create interest. It didn't.

In preparing for this article, I spoke with others from my fellowship class to get their reactions to the placement experience. One fellow recalled being interviewed by Senate staffers who were confident that academics were probably wholly unfit for the fast paced and deadline driven environment of the Capitol. Perhaps they are correct. But as a central source of training for future congressional staffers, scholars who teach about Congress must prepare students for this reality. That requires creating assignments that train students to be effective communicators in a professional setting, where conciseness on a deadline is valued.

The flow of information to members of Congress from committee staff is heavily filtered. My boss, Mr. Clay, served on three committees: Oversight and Government Reform, Financial Services, and Natural Resources. Many mid-week mornings when the House was in session, each of these committees was conducting hearings. While each committee's partisan staff works diligently to ensure that members are prepared for hearings, it is dependent on staff (legislative assistants, fellows, interns) to convey the rich detail of the committee staff memos to the members directly. Staff must to be ready to brief their members over hours of hearings or in detailed briefing memos in as little time as possible. 
Given the information rich and time-constrained environment, the "one-pager" memo is an important currency. Lobbyists and other advocates who come to the Hill for meetings know this, and the best prepared will have a glossy fact sheet to accompany each position, bill, or appropriations request they push. This information, particularly in its short, accessible form is incredibly valuable to members and their and poking" and the work of fellows. We are part of the team, not passive observers.

I hope that Fenno makes it into your undergraduate courses. But, there are a number of ways to bring Home Style into the classroom. The behavior of members at home-namely during campaigns, district work periods, and other constituent centered events-is central to understanding congressional behavior.

\section{... as a central source of training for future congressional staffers, scholars who teach about Congress must prepare students for this reality. That requires creating assignments that train students to be effective communicators in a professional setting, where conciseness on a deadline is valued.}

staff. One assignment I use is to have students choose a bill from the "Top 10 Most-Viewed Bills" list on Congress.gov and create a one-pager directed at their member of Congress, or a member of their choosing. In the memo, students outline the major provisions of the bill, the impact on the district, supporters and opponents of the bill, the progress of the bill and likelihood of a floor vote, and a vote recommendation for the member given past positions. This type of memo is exactly the kind of work product expected from congressional staff, but it also illuminates the conceptual knowledge of interest groups, the legislative process, and member ideology that would be central in a course on Congress.

For those faculty members who believe a course is incomplete without a detailed research paper, adding the "one pager" policy memo need not replace traditional assignments. One text I consult for creating new assignments to push critical thinking is Bean's (2011) Engaging Ideas. Bean advocates using a wide variety of "genres" that includes academic writing, but also personal writing (journals, blogs), civic writing (Op-ed, posters), and professional writing (memos, cover letters, press releases). There is still a place for evaluating student knowledge through thoughtful critiques of theories in legislative politics through reflection papers, literature reviews, and research papers. However, in the trenches of committee rooms and member offices, the clarity of concise writing is highly valued. Our assignments should reflect that reality.

\section{CONSTITUENTS AND CONSTITUENCIES: STYLE AND "HOME STYLE" ON THE HILL}

Students of Congress, and the political science community more broadly, will be familiar with Fenno's argument that scholars should pay more attention to the individual behavior of members of Congress in their districts (2003a, see also Fenno 2003b and Parker 2015). This often repeated axiom has changed little in the subfield of legislative studies, despite the sincerity and enthusiasm of those who repeat it. However, the APSA Congressional Fellowship Program is one area where participant observation is alive and well. If you speak with current or former fellows, they will have more than a handful of stories that give insight to the individual decision-making process. There is an obvious distinction between "soaking
But there is a distinct "Home Style" for members, even when they are in Washington. The key insight of the individualist perspective is that Congress is really a series of 541 fiefdoms. One of the best textbooks on Congress, Congress and its Members, frames the discussion as understanding the "Two Congresses" where "lawmaking and representing are separate tasks, and members of Congress recognize them as such. Yet these two Congresses are bound together. What affects one affects the other-sooner or later" (Davidson et al. 2016, 5).

One of the easiest ways to see the dynamics of the "Two Congresses" on display is in the speeches of "Morning Hour" on the floor of the House of Representatives. These speeches may reference legislation, but their focus is most often representation rather than lawmaking. These speeches are conducted through unanimous consent procedures and give members a chance to create a floor record. The diversity of opinions, speaking styles, and humor levels among members is on display during these speeches. Between one and five minutes long, they do not take up much class time, and the laughs they bring can be effective at getting students thinking for the day. They are a great source of examples for Mayhew's (1974) description of credit claiming, position taking, and advertising.

The general speeches of "Morning Hour" provide an insight into the speed and traction of partisan messaging that takes place through the use of on-the-record speeches from the well. In June 2016, the country was shaken by the tragic death of 49 individuals at the Pulse Nightclub in Orlando. The response to this horrific event by members of Congress is an important case study on the nature of the contemporary conflicts that take place on the Hill (and in the public at large). Following the shooting, there were 19 members given floor time during "Morning Hour," nine Democrats and ten Republicans. All but two Democrats gave a speech referencing Orlando. Only two Republicans, Mr. Dold of Illinois and Mr. Thompson of Pennsylvania, gave a speech referencing the attack. The other eight Republicans took to the floor to honor the Farm Credit System, warn of the "Baby Body Parts Industry," and then highlight the importance of small businesses. After a recess, 15 one-minute speeches were given from the well, largely reflecting the same partisan messaging outlined 
in the morning, but with a concentrated focus on background checks and gun loopholes from the Democrats.

Outside of "Morning Hour" speeches, there are a number of ways to include the diversity of strategies and styles of members. The Hill newspaper Roll Call has a written and video series called "Office Space" where you can tour the offices of some members virtually and see how the represent themselves and their districts. The three newspapers covering Capitol Hill (Roll Call, Politico, The Hill) operate somewhat like a campus newspaper, covering both culture and hard news.
Mr. Clay's office even had a number of small stuffed bison to give to visiting children. These opportunities to represent are an important part of the congressional environment, and often the only source of legislative success in a deadlocked Congress.

\section{THE CASE METHOD: CONTROVERSIES, CULTURE WARS, AND THE CONGRESSIONAL ART COMPETITION}

The "case method" is a pedagogical approach, most commonly associated with law and business schools, where students

\section{One of the easiest ways to see the dynamics of the "Two Congresses" on display is in the speeches of "Morning Hour" on the floor of the House of Representatives. These speeches may reference legislation, but their focus is most often representation rather than lawmaking.}

While they are great sources for insider perspectives on activities around Congress, they also provide rich coverage of members' non-legislative activities around the Capitol. Legislative strategy and campaign rumors mix with roster expectations for the upcoming Congressional Baseball Game. Using these resources, faculty and students can view the inside world of the Hill community that fellows see up close.

My research focuses on the dynamics of representation in the House of Representatives. I sought out a placement that would help me explore these issues. I was lucky to find a desk in the office of Rep. William Lacy Clay, Jr. from Missouri's First District. The first includes the City of St. Louis and surrounding communities like Ferguson, a flash point in ongoing controversies about the state of race in America. His father, William Clay, Sr. was a founding member of the Congressional Black Caucus and held the first district seat for 32 years. Mr. Clay, Jr. has never received less than $70 \%$ of the vote in a general election for the House. As a member of the minority party, the Congressional Black Caucus, and the liberal Congressional Progressive Caucus, most legislative initiatives Clay might champion had little chance of success in the Republican led House.

Members of Congress who serve in "safe" seats in the minority party have a voice in their committees and on the House floor, but little access to other levers of the textbook legislative process. The only successful bill Mr. Clay pushed in the 114th Congress was the "National Bison Legacy Act" that made the North American bison the official mammal of the United States. This bill was pushed by a unique coalition that included Native American Republican Rep. Kristi Noem (SD-At large), a Puerto Rican Democrat from the Bronx, José Serrano (NY-15) whose local Bronx Zoo was responsible for breeding the herd that brought back the bison, and Mr. Clay, a descendent of Buffalo Soldiers. ${ }^{1}$ Guided by a diversity of representational motivations (as well as the support of lobbyists representing bison ranchers armed with delicious bison jerky for each office) these members were able to take action that recognized the heritage and culture of their constituents. focus on a case or a series of cases to expose students to the situational nature of decision making within institutions. In law or business, one might teach the specific decisions made by Steve Jobs or Earl Warren not just to provide an opportunity for critical thinking and analysis of that choice, but also to provide broader lessons on the nature of the institutions and environments in which they operate. After a year in Congress, fellows accumulate a number of "cases" that provide rich detail and demonstrate broader lessons. Some are personal and come from a fellow's interaction and work in their offices. Often, however, these cases come from staffers, other fellows, or even from the members themselves. The "National Bison Legacy Act" and the "Morning Hour" speeches given in the aftermath of the Orlando Shooting are two cases I use frequently.

Many of the best cases come from the culture wars where controversy comes in the form of disputes around political culture, morality, and policy. The extent of the culture wars is the subject of robust scholarly debate, but there is no doubt that arguments around guns, abortion, race, LGBT issues, "religious freedom," and even our school lunch salt content makes up a significant portion of political conversation. Thinking about the ways that members, caucuses, committees, and parties respond to these controversies provide excellent case studies to bring to the classroom.

My experience as an APSA fellow gave me the chance to literally touch the culture wars. Each member of Congress sponsors an art competition for high school students, with the winners receiving a trip to DC to see their art hung in the Capitol complex. This work usually falls to staff in the district, but DC-based help is necessary. I delivered the winning piece from Missouri's First District, "Untitled \#1" by David Pulphus, to the Architect of the Capitol in May of 2016 and helped Mr. Pulphus and his family get to the art competition events. In late December as the Congress recessed in preparation for the arrival of new members, the piece came to the attention of talk radio and cable television personalities. "Untitled \#1" is difficult piece to describe, but it reflects the atmosphere of 
St. Louis and Ferguson. In the foreground of the piece, a human like black panther with a fist out faces a horned-pig in police uniform with a gun drawn. Among political commentators, it is more common to hear the work titled "Cops as Pigs" rather than "Untitled \#1." Rep. Duncan Hunter (R-CA) took the piece down and returned it to Rep. Clay's office. It would be taken down by Republican members and rehung by Clay and staff multiple times that week. The Architect of the Capitol ordered the removal of the painting, and a First Amendment lawsuit is now in progress in federal court, where noted professor Lawrence Tribe is assisting the legal effort demanding the painting be rehung. The culture war moves from canvas to Congress to the courtroom.

\section{CONCLUSION: BRINGING THE HILL HOME}

The APSA Congressional Fellowship Program's mission of "expanding knowledge and awareness of Congress" is strengthened with every new class of fellows. For members of the academy, the expansion of knowledge is mostly measured in refereed articles, books, and other scholarly production. The "practical" knowledge of Congress is distributed from members of Congress and their staff to the fellows, who then enrich the quality of academic debate through their experiences. There is no doubt in my mind that the CFP achieves its mission in the academy. But the area of greatest impact for the program may be in how we teach our undergraduatesthe voters, journalists, hill staffers, or even members of Congress of the future. We should take this avenue for increasing awareness of Congress seriously.

Congress is an exciting place. Those who teach Congress should try to convey that same enthusiasm and excitement (Baum 2002). The centrality of Congress in American government and society necessitates updating our examples and assignments. Effective teaching strategies to prepare students to understand the institution, both from the inside and outside, are needed. Based on my experience as a fellow, I suggest a few strategies: create meaningful and relevant assignments, find stimulating ways to highlight the personalities and individual incentives of members, and use the recent and relevant controversies as an entry point into your discussions.

\section{ACKNOWLEDGMENTS}

Kara Abramson, CFP director, and the APSA staff were incredibly valuable resources and friends during the fellowship year, thanks for everything. Fellow fellows Lisa Hager and Nick Howard, and an anonymous reviewer offered helpful feedback on this piece.

\section{NOTE}

1. The "Buffalo Soldiers" were black regiments organized to fight the various "Indian Wars" in the West. The Cheyanne said they fought with the resilience of a cornered buffalo, taking wounds but refusing to die.

\section{REFERENCES}

Baum, Lawrence. 2002. "Enthusiasm in Teaching." PS: Political Science E Politics 35 (1): 87-90.

Bean, John C. 2011. Engaging Ideas: A Professors Guide to Integrating Writing, Critical Thinking and Active Learning in the Classroom. 2nd ed. New York: Wiley.

Clay, Sr. William L. 1992. Just Permanent Interests: Black Americans in Congress 1870-1991. New York: Amistad Press.

Davidson, Roger H., Walter J. Oleszek, Frances E. Lee, and Eric Schickler. 2016. Congress and Its Members, 14th ed. Washington, DC: CQ Press.

Fenno, Richard. 2003a. Home Style: House Members in their Districts. New York: Longman.

_. 2003b. Going Home: Black Representatives and Their Constituents. Chicago: University of Chicago Press.

Mayhew, David. 1974. Congress: The Electoral Connection. New Haven: Yale University Press.

Parker, David C. W. 2015. The Battle for the Big Sky: Representation and the Politics of Place in the Race for the US Senate. Washington, DC: CQ Press. 